with a mouse," he said. If anyone believed the Commission should go through that kind of agony again, he was mistaken, said the Commissioner. The Commission should scuttle programmes far sooner when member states do not agree.

Not that Davignon is against Community support for biotechnology far from it. Rather, he appears to detest the national bickering which delayed the programme so long. His policy now is to set up a "framework for research", a broad structure of ministerial agreement on Brussels research and development policy. The framework would stretch over, say, five years, leaving the Commission room to develop detailed programmes within the

\section{Fusion decision awaited}

\section{Brussels}

The next EEC research council on $8 \mathrm{March}$ is now likely to approve the next five-year programme on controlled thermonuclear fusion. The fear that there might be a gap in the sliding programmes, between the last budgetary allocation and this, was further reduced with the release last week of a favourable opinion from the Consultative Committee for the Fusion Programme, which considers the planned financial envelope $-1,500$ million European Currency Units ( $£ 750$ million) has been allowed.

Continued membership by Sweden, one of the two non-EEC countries participating, is, however, in jeopardy. The committee observes that Sweden finds the cost excessive. One difficulty is that neither Sweden nor Switzerland participates in the EEC's annual budgetary procedure, when the amount of money devoted to a programme can be adjusted. National contributions are assessed on the basis of a percentage of gross national product, and for Sweden more money for the EEC programme means less for national research.

The Commission's thermonuclear research strategy, which is to concentrate effort on the tokamak line while retaining an interest in magnetic confinement, reverse field pinch and stellerators, wins the approval of the committee, which nevertheless recommends a periodic assessment of the relevance of these side-lines to reactor development.

The committee is, however, more cautious in its views on the step to be taken after JET, the Joint European Torus now nearing completion at Culham in Britain. It recommends that plans for the next large thermonuclear machine, called NET (for Next European Torus), should be reviewed again before a decision is made in 1984. Likewise the committee is noncommittal on the need for the proposed tritium laboratory. guidelines and giving nation states the chance to see a fair return on Community investment in a much wider context.

This framework is to be thrashed out in the next two meetings of the Council of Ministers for research, one in March and the next in June. If nothing happens in 1982, the momentum will be lost, says Davignon. But the transition from the present structure to the new one will be gradual. Some heads have already rolled at the Directorate-General for Research, but Davignon's cabinet insists that the night of the long knives will not last long. The objective is to use existing staff in new ways, Davignon claims - although some Commission staff remain nervous.

And to what end? To revitalize European industry. Davignon, whose commission also covers energy and industry affairs, says Brussels research and development has a way of redirecting European economic development, to fill gaps - such as in telematics and computers - in relation to the Japanese and United States competition. To achieve this, Davignon is prepared to be surprisingly flexible, and sees a role for the Commission even in helping to set up bilateral research and development projects among member states, and in giving international promotion to national centres of excellence. Davignon hopes member states will agree to his ambitious programme because of the economic risks involved in not doing so.

Robert Walgate

\section{US university funding}

\section{Tax act fails}

\section{Washington}

Universities in the United States are complaining that so far they have benefited little from the Reagan Administration's attempts to augment spending on research by tax cuts rather than direct support.

On the one hand, the tax cuts were structured in such a way that it has been equally, if not more, tempting to a company to increase its internal research efforts rather than contract work to outside groups. On the other, there is a feeling that the new incentives will have little effect on some of the largest companies which already have relatively low tax liabilities.

Two parts of the Economic Tax Recovery Act signed by President Reagan last summer were supposed to help universities, one a tax credit designed to increase industry support for basic research at universities, the other a new deduction for industries contributing research equipment to universities.

"Neither appears to hold significant promise," Dr John C. Crowley of the Association of American Universities (AAU), which follows legislative affairs for the major US research universities, told a recent meeting of the American Association for the Advancement of Science.
Dr Crowley quoted a letter from Mr B.J. McKelvain, an analyst with General Electric Company, which has been among the most aggressive companies seeking tax incentives to boost spending on research and development. Mr McKelvain presents the company's estimate that the research tax credit will result in an increase of less than two per cent in industry-funded research.

The difference in the incentive for increased support of university research compared with in-house work is probably "negligible", Mr McKelvain had written. And although he says that the incentive for equipment donations should result in some increased giving, "we would not expect the response to have a significant impact on the critical shortage of state-of-the-art equipment available for university research".

The principal reason for this pessimistic assessment is based on the narrow scope of the tax provisions. For example, any equipment donated by a company must have been manufactured by that company and cannot contain purchased parts accounting for more than 50 per cent of the tax costs.

"Despite these limitations, the equipment donation provision is a start in the right direction. If broadened somewhat, it could have a considerable impact on the problem", said Dr Crowley, one of the coauthors of a report prepared by AAU for the National Science Foundation two years ago. This formed the basis for the Carter Administration's proposal to provide an additional $\$ 7$ million in the foundation's budget for university research equipment, but was one of the first items to be cut by the Reagan Administration when it came to power last January.

As for the broader impact of the new tax laws, Dr Crowley concludes that the 1981 Tax Act offers "only token incentives for research support and donations of research equipment by industry".

This view is confirmed by officials from several major universities. $\mathrm{Mr}$ Stuart H. Cowen, for example, vicepresident for financial arrangements at the Massachusetts Institute of Technology, said that, so far, the institute had "not seen much effect of the new tax law", although speculating that companies may be holding back until the Treasury Department publishes detailed guidelines on how the law will be interpreted.

Although disappointed, few university officials are surprised at the apparent failure of the bill. Whereas they had pushed hard for inclusion in the tax legislation of a clause allowing companies to write off all contributions to university basic research against tax, the Treasury Department was not convinced that the value of this move would outweigh the costs in terms of lost revenue; the bill as finally passed by Congress merely allows for tax relief on the amount that support for such research is increased by a company.

Several congressmen are hoping to 